\title{
Preharvest Changes in the Physical and Chemical Properties of Plantains
}

\author{
F. Sánchez Nieva, G. Colom Covas, I. Hernaindez, R. Guadalupe, N. Diaz, and \\ C. B. Viñas
}

\section{INTRODUCTION}

Plantains are widely used as food throughout the Tropics. Few attempts have been made to process the fruit commercially, except for the production of a flour by sun-drying or mechanical methods. López $(1)^{2}$ and later Rahman (2) studied procedures for the production of the flours in Puerto Rico. Although, a flour with a pleasing taste and a protein content of about 3.5 percent can be prepared, this product has not been well accepted by consumers.

The production of plantains in Puerto Rico is estimated at 235,000 (thousand) lots of fruits with a farm value of $\$ 6,251,000$ ( 8 ). Although the fruit is generally available throughout the year, there is a surplus during the summer, with the result that prices drop at this time of the year. In an effort to find an outlet for this crop, the Food Technology Laboratory of the Agricultural Experiment Station of the Unviersity of Puerto Rico has been conducting studies with the objective of developing new products from plantains. Cancel et al. (4) developed procedures for the commercial processing of plantain chips and Sánchez and Hernández worked out methods for the preparation of frozen ripe plantains in syrup (5). Other work in progress points to the feasibility of preparing other products from plantains.

From an early stage, these investigations showed that the quality of the processed products depends on the stage of maturity at which plantains are processed. No information could be found in the literature on the preharvest changes in the physical and chemical properties of plantains, nor on the criteria to be used for harvesting. Consequently, a series of field experiments was conducted to study the changes taking place from fruit-set to harvesting, and to determine the characteristics which could be used to harvest the fruit at a proper stage for processing.

This study is conerned with some of the changes in physical and chemical

1 Technical Director, Associate Horticulturist, Assistant Chemical Engineer and Research Assistants respectively, Food Technology Laboratory, Agricultural Experiment Station, Mayagüez Campus, University of Puerto Rico, Río Piedras, P.R. The authors wish to express their gratitude to A. Rodriguez Cabrera, formerly in charge of the Corozal Substation, for cooperation given in the field experiments.

2 Italic numbers in parentheses refer to Literature Cited, pp. 254-5. 
properties which take place before plantains are harvested, and with the development of suitable harvesting indices.

\section{MATERIALS AND METHODS}

Field experiments were carried out at the Corozal Substation. The two cultivars most planted by farmers were used, generally known as Maricongo and Guayamero. In the earlier part of these studies, plantains of the Guayamero cultivar were obtained from a plantation established for seed production by the Seed Farm Division of the Agricultural Experiment Station.

Later, two experimental plots of 200 plants each of the Guayamero and Maricongo cultivars were established. Planting material for the Guayamero plot was obtained from the plantation previously used. Planting material for the Maricongo cultivar was purchased from a farmer known to produce plantains of fairly uniform characteristics.

The plants were planted at a distance of $5 \times 10$ feet. Corms ranged in weight from 1 to 4 pounds. Before planting, the corms were treated with a solution of 1.5 liters of Aldrin per 10 gallons of water to control the banana borer Cosmopolites sordidus, G. After tilling the soil, filter-press cake was added. Fertilizer formula 9-10-5 was applied at the rate of 4 pounds per plant in four applications 2 months apart. Six months after planting, the soil was treated with a solution of Aldrin of the same strength as used for treating the corms. The plants were sprayed with orchard-spray oil every 15 days to control the Sigatoka leaf spot disease. No followers were allowed to grow.

Bunches were harvested at different ages and taken to the laboratory for physical and chemical determinations. Each bunch was weighed with the stem attached, but with the male bud and stem cut-off closed to the last hand. Hands and fingers were counted. The average weight of fingers was determined by weighing a number of fruits and averaging the weights. Fingers from the third hand were peeled and the percentage of pulp and peel determined by weight. Pulp:peel ratios were calculated from average weights of pulp and peel.

To determine the configuration of the cross-sectional area and the angularity of the fruit, a section from the center of fingers from the third hand was cut and photographed. Outlines of the cross sections were also traced in paper. The longer and shorter diameters were measured directly on the fruit with a caliper as indicated on figure 1. Length of the fruit was measured in inches.

Only the peeled fruit was used for chemical analyses. Starch was determined by the method of Carter and Neubert (6). Reducing and total sugars were determined by the Moyer and Holgate method (7), inverting 
with invertase for total sugar determinations. Acidity and $\mathrm{pH}$ were measured by the A.O.A.C. glass-electrode method (8).

Texture was measured with a Lee-Kramer electrical recording and indicating press with a 5,000-pound proving ring, with the range set for 2,000 pounds. The plunger was adjusted to move at $1.5 \mathrm{~mm}$. per second. A standard shear-cell was used for all determinations. To make a measurement, the plantains were peeled and cut in halves lengthwise. The slices were cut in lengths to fit the cell and placed perpendicular to the path of the knives. The cell was packed full, which generally required about 8
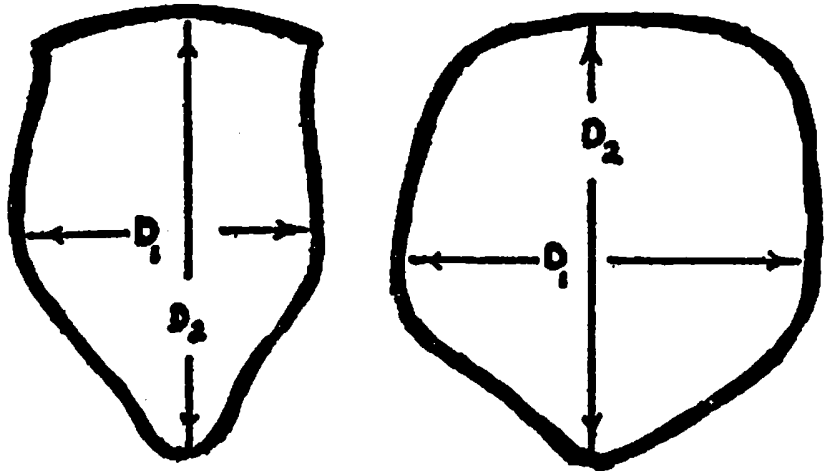

\section{D, SHORTER DIAMETER \\ $D_{2}$ LONGER DIAMETER}

FIG. 1.-Method of measuring the shorter and longer diameter of plantains.

ounces of the sliced fruit. The time:force curve was recorded and the maximum pressure applied was read directly from the chart.

\section{RESULTS AND DISCUSSION}

The characteristics of the fingers from the different hands of bunches harvested from 70 to 109 days after the inflorescence was visible are shown in table 1. These data were taken from bunches of similar visual characteristics harvested from among 300 plants. Since great variations in the size and appearance of the fruit were observed in more than 500 bunches harvested in the course of these studies, the data in table 1 should be taken only as indicative of the trends of the changes taking place as the plantains mature before harvesting. 
TABLE 1-Characteristics of fingers from the different hands of bunches plantain harvested at the ages indicated, Guayamero cultivar

\begin{tabular}{|c|c|c|c|c|c|c|c|c|c|}
\hline \multirow{3}{*}{$\begin{array}{l}\text { Hand } \\
\text { No. }\end{array}$} & \multirow{3}{*}{$\begin{array}{c}\text { Average } \\
\text { weight } \\
\text { (oz.) }\end{array}$} & \multicolumn{2}{|c|}{ Length (inches) } & \multicolumn{4}{|c|}{ Cross-section dimensions (inches) } & \multirow{3}{*}{$\begin{array}{c}\text { Texture: } \\
\text { Shear-press } \\
\text { maximum- } \\
\text { force } \\
\text { values } \\
\text { (lb./sq. in.) }\end{array}$} & \multirow{3}{*}{$\begin{array}{l}\text { Pulp: } \\
\text { peet } \\
\text { ratio }\end{array}$} \\
\hline & & \multirow{2}{*}{ Range } & \multirow{2}{*}{ Mean } & \multicolumn{2}{|c|}{ Larger diameter } & \multicolumn{2}{|c|}{ Smaller diameter } & & \\
\hline & & & & Range & Mean & Range & Mean & & \\
\hline \multicolumn{10}{|c|}{ Age-70 days } \\
\hline $\begin{array}{l}1 \\
2 \\
3 \\
4 \\
5 \\
6 \\
7 \\
8\end{array}$ & $\begin{array}{l}7.6 \\
6.8 \\
7.0 \\
5.7 \\
6.4 \\
5.3 \\
5.3 \\
4.0\end{array}$ & $\begin{array}{l}7.3-9.3 \\
8.3-9.0 \\
7.8-8.8 \\
6.8-8.3 \\
7.0-8.8 \\
7.0-8.0 \\
6.5-8.0 \\
6.3-7.5\end{array}$ & $\begin{array}{l}8.3 \\
8.5 \\
8.2 \\
7.6 \\
8.1 \\
7.5 \\
6.8 \\
6.8\end{array}$ & $\begin{array}{l}1.5-1.9 \\
1.4-1.8 \\
1.4-1.6 \\
1.4-1.9 \\
1.5-1.7 \\
1.4-1.6 \\
1.3-1.6 \\
1.5-1.5\end{array}$ & $\begin{array}{l}1.7 \\
1.6 \\
1.5 \\
1.5 \\
1.6 \\
1.5 \\
1.4 \\
1.5\end{array}$ & $\begin{array}{l}1.3-1.6 \\
1.4-1.5 \\
1.4-1.5 \\
1.3-1.4 \\
1.4-1.5 \\
1.3-1.4 \\
1.1-1.3 \\
1.2-1.3\end{array}$ & $\begin{array}{l}1.4 \\
1.4 \\
1.4 \\
1.3 \\
1.4 \\
1.4 \\
1.3 \\
1.3\end{array}$ & $\begin{array}{l}1,660 \\
1,550 \\
1,600 \\
1,550 \\
1,320 \\
1,500 \\
1,400 \\
1,460\end{array}$ & $\begin{array}{l}1.33 \\
1.30 \\
1.32 \\
1.29 \\
1.32 \\
1.37 \\
1.18 \\
1.27\end{array}$ \\
\hline \multicolumn{10}{|c|}{ Age -88 days } \\
\hline $\begin{array}{l}1 \\
2 \\
3 \\
4 \\
5 \\
6 \\
7\end{array}$ & \begin{tabular}{r|}
11.0 \\
9.1 \\
9.0 \\
8.6 \\
7.4 \\
8.0 \\
6.7
\end{tabular} & $\begin{array}{l}9.5-11.0 \\
8.3-10.0 \\
8.0-10.0 \\
8.3-9.5 \\
8.0-9.8 \\
8.0-9.0 \\
7.0-7.5\end{array}$ & \begin{tabular}{r|}
10.6 \\
9.1 \\
9.1 \\
8.9 \\
8.7 \\
8.5 \\
7.3
\end{tabular} & $\begin{array}{l}1.7-2.1 \\
1.6-1.9 \\
1.6-1.8 \\
1.6-1.9 \\
1.5-2.0 \\
1.6-1.8 \\
1.5-1.6\end{array}$ & $\begin{array}{l}1.9 \\
1.7 \\
1.7 \\
1.8 \\
1.7 \\
1.7 \\
1.6\end{array}$ & $\begin{array}{l}1.7-2.1 \\
1.6-1.9 \\
1.6-1.8 \\
1.6-1.9 \\
1.5-2.0 \\
1.6-1.8 \\
1.5-1.6\end{array}$ & $\begin{array}{l}1.9 \\
1.7 \\
1.7 \\
1.8 \\
1.7 \\
1.7 \\
1.6\end{array}$ & $\begin{array}{l}1,380 \\
1,440 \\
1,325 \\
1,340 \\
1,140 \\
1,260 \\
1,350\end{array}$ & $\begin{array}{l}1.46 \\
1.46 \\
1.40 \\
1.48 \\
1.37 \\
1.38 \\
1.44\end{array}$ \\
\hline \multicolumn{10}{|c|}{ Age-92 days } \\
\hline $\begin{array}{l}1 \\
2 \\
3 \\
4 \\
5 \\
6 \\
7 \\
8\end{array}$ & \begin{tabular}{r|}
15.0 \\
12.8 \\
12.8 \\
11.5 \\
10.2 \\
11.2 \\
9.6 \\
6.9
\end{tabular} & $\begin{array}{r}10.0-11.5 \\
9.8-10.8 \\
10.0-11.0 \\
9.0-10.0 \\
8.0-9.8 \\
9.0-9.8 \\
9.3-8.5 \\
7.8-9.0\end{array}$ & $\begin{array}{r}10.7 \\
10.3 \\
9.4 \\
9.6 \\
8.8 \\
9.3 \\
8.9 \\
8.3\end{array}$ & $\begin{array}{l}1.9-2.3 \\
1.9-2.1 \\
1.8-2.2 \\
1.9-2.0 \\
1.6-2.2 \\
1.8-1.9 \\
1.6-1.9 \\
1.6-1.8\end{array}$ & \begin{tabular}{l|}
2.1 \\
1.9 \\
1.9 \\
1.9 \\
1.8 \\
1.9 \\
1.8 \\
1.8
\end{tabular} & $\begin{array}{l}1.8-2.1 \\
1.7-1.9 \\
1.7-1.9 \\
1.61 .9 \\
1.6-1.9 \\
1.7-1.9 \\
1.4-1.7 \\
1.5-1.6\end{array}$ & $\begin{array}{l}1.9 \\
1.8 \\
1.8 \\
1.8 \\
1.7 \\
1.8 \\
1.8 \\
1.6\end{array}$ & $\begin{array}{l}1,160 \\
1,170 \\
1,280 \\
1,220 \\
1,260 \\
1,160 \\
1,160 \\
1,160\end{array}$ & $\begin{array}{l}1.59 \\
1.59 \\
1.65 \\
1.61 \\
1.83 \\
1.70 \\
1.49 \\
1.47\end{array}$ \\
\hline
\end{tabular}

Age-109 days

\begin{tabular}{l|r|r|r|r|r|r|r|r|r}
\hline 1 & 15.2 & $10.0-11.8$ & 10.9 & $1.9-2.3$ & 2.1 & $1.8-2.1$ & 1.9 & 920 & 1.98 \\
2 & 14.2 & $10.0-11.5$ & 10.6 & $1.8-2.3$ & 2.0 & $1.8-2.1$ & 1.9 & 970 & 1.78 \\
3 & 12.5 & $9.0-11.0$ & 10.0 & $1.8-2.1$ & 2.0 & $1.6-1.9$ & 1.9 & 1,120 & 1.86 \\
4 & 12.9 & $9.3-10.5$ & 9.9 & $1.8-2.1$ & 1.9 & $1.8-2.1$ & 1.9 & - & 1.79 \\
5 & 12.8 & $10.0-11.0$ & 10.6 & $1.8-2.1$ & 1.9 & $1.7-1.9$ & 1.8 & 1,020 & 1.86 \\
6 & 11.2 & $8.5-9.5$ & 8.9 & $1.8-2.1$ & 1.9 & $1.8-1.8$ & 1.8 & 970 & 1.75 \\
7 & 9.3 & $7.8-8.3$ & 8.0 & $1.8-2.1$ & 1.8 & $1.4-1.8$ & 1.7 & 1,190 & 1.72 \\
\hline
\end{tabular}


The average weight of the fingers from all hands increases with age, but levels off around 92 days. The weight of the fingers decreases in the order of emergence of the hands. Irrespective of maturity, the same relative difference in the weights of the fingers among the different hands is observed.

The fingers attain their final length before their weights level off. The length of the fingers from the different hands varies also according to the order of emergence. It should be noted that the fruits from the middle hands are similar in size, but those from the first hand are longer than those from the last.

A similar trend is observed in the cross-sectional dimensions. The fingers from the middle hands have similar cross-section dimensions, while the fingers from the first hand are more plump than those from the last. Plumpness of the fruit increases with age.

Table 2.-Chemical composition (percent) of fingers from the third hand of plantain bunches of the Guayamero cultivar harvested at the ages (days) indicated

\begin{tabular}{l|r|r|r|r|r|r|r}
\hline \multicolumn{1}{c|}{ Characteristics measured } & \multicolumn{1}{c|}{70} & \multicolumn{1}{c|}{79} & \multicolumn{1}{c|}{83} & \multicolumn{1}{c|}{86} & \multicolumn{1}{c|}{100} & \multicolumn{1}{c|}{104} & \multicolumn{1}{c|}{106} \\
\cline { 2 - 6 } Starch (percent) & 32.84 & 33.72 & 33.04 & 32.42 & 32.44 & 33.07 & 33.05 \\
Total sugars as invert (do.) & .41 & .47 & .50 & .51 & .53 & .53 & .44 \\
Reducing sugars (do.) & .09 & .16 & .32 & .09 & .30 & .26 & .40 \\
$\begin{array}{l}\text { Total acidity as anhydrous } \\
\text { citric acid (do.) }\end{array}$ & .15 & .21 & .20 & .17 & .16 & .21 & .20 \\
pH & 5.60 & 5.96 & 5.90 & 5.56 & 5.67 & 5.97 & 5.85 \\
\hline
\end{tabular}

The texture of the fingers from all the hands at any age have similar values, but shear press measurements indicate a definite trend for pressure values to decrease as the bunch matures, indicating softening of the fruit.

Pulp:peel ratios have similar values for all hands at any age, but as the bunch matures, the ratio increases, indicating an increase in the weight of the pulp and a decrease in the weight of the peel.

The chemical composition of the fingers from the third hand from bunches harvested at different ages is shown in table 2. No changes in starch, total sugars, acidity, or $\mathrm{pH}$ were observed to take place as the bunch matures on the plant. There seems to be a slight tendency for reducing-sugar values to increase with maturity.

The data in table 1 suggest that, possibly, cross-sectional dimensions, texture values measured with the shear press and pulp:peel ratios may be used to indicate changes in maturity. In order to find which of these measurements is more reliable and suitable to be used as a maturity index, a large number of bunches were harvested at different ages. Cross-sectional dimensions, pulp: peel ratios, and texture were measured on the fruit from 
the third hand of each bunch. The weight of each bunch harvested was also recorded.

Cross-sectional dimensions for plantains harvested at different ages are given in table 3 . The results of correlation analyses of the variation of cross section dimensions with age are given in the following tabulation:

Correlations tested

Longer diameter

Shorter diameter

Ratio of longer to

shorter diameter

Correlation coefficients

\begin{tabular}{cc}
\hline Calculated & at 5 percent \\
0.28 & 0.51 \\
.32 & .51 \\
.20 & .51
\end{tabular}

No significant correlation was found between the larger or smaller diameter, or the ratio of the two with age. Analyses of the data from other plots

TABLE 3.-Longer and shorter dimensions of plantains at different stages of development, Guayamero cultivar

\begin{tabular}{c|c|c|c}
\hline $\begin{array}{c}\text { Age range } \\
\text { (days) }\end{array}$ & $\begin{array}{c}\text { Larger diameter } \\
(\mathrm{A})\end{array}$ & $\begin{array}{c}\text { Shorter diameter } \\
(\mathrm{B})\end{array}$ & $\begin{array}{c}\text { Ratio } \\
\mathrm{A} / \mathrm{B}\end{array}$ \\
$70-75$ & Inches & Inches & \\
$76-80$ & 1.50 & 1.43 & 1.05 \\
$81-85$ & 1.75 & 1.54 & 1.13 \\
$86-90$ & 1.73 & 1.56 & 1.11 \\
$91-95$ & 1.79 & 1.64 & 1.09 \\
$96-100$ & 1.94 & 1.75 & 1.11 \\
$101-105$ & 1.77 & 1.60 & 1.10 \\
$106-110$ & 2.00 & 1.81 & 1.10 \\
& 1.87 & 1.74 & 1.08 \\
\hline
\end{tabular}

of the Guayamero and Maricongo cultivars also failed to show any significant correlation of the ratios of the diameters with age as shown by the data in table 4.

Figure 2 shows how the angularity of the fruit changes with age. As the fruit matures, the plumpness of the fruit increases, the fruit becoming more rounded. In figure 3 , photographs of the cross sections of plantains harvested at different ages are shown. The wide variation in the configuration of the cross-sectional area should be noted, which may account for the failure to correlate cross-sectional dimensions with age or stage of development. Probably owing to variations in plant vigor, plantains may have an appearance that does not correspond with their age or stage of development. This was observed to be the case with many of the bunches harvested.

A significant correlation was found between age and pulp:peel ratios in both cultivars. Correlation coefficients for the Guayamero cultivar were 
TABLE 4.-Correlation of age with average weight of fruit, ratio of pulp:peel weights. and ratio of diamelers for 2 cullivars of planlains

\begin{tabular}{l|l|l|c}
\hline \multicolumn{1}{c|}{$\begin{array}{c}\text { Correlation tested } \\
\text { (age with) }\end{array}$} & Cultivar & $\begin{array}{c}\text { Calculated } \\
\text { correlation } \\
\text { coefficient }\end{array}$ & $\begin{array}{c}\text { Level of } \\
\text { significance }\end{array}$ \\
\hline Average weight of fruit & $\begin{array}{l}\text { Guayamero } \\
\text { Maricongo }\end{array}$ & $\begin{array}{c}0.16 \\
.3316\end{array}$ & $\begin{array}{c}\text { N.s.1 } \\
5 \text { percent }\end{array}$ \\
Ratio of pulp:peel weights & $\begin{array}{l}\text { Guayamero } \\
\text { Maricongo }\end{array}$ & $\begin{array}{l}.2515 \\
.3260\end{array}$ & $\begin{array}{c}5 \text { percent } \\
1 \text { percent }\end{array}$ \\
Ratio of diameters & $\begin{array}{l}\text { Guayamero } \\
\text { Maricongo }\end{array}$ & .2087 & .0587 \\
Shear-press maximum force & Guayamero & .836 & N.S.1 \\
\hline
\end{tabular}

1 Not significant.

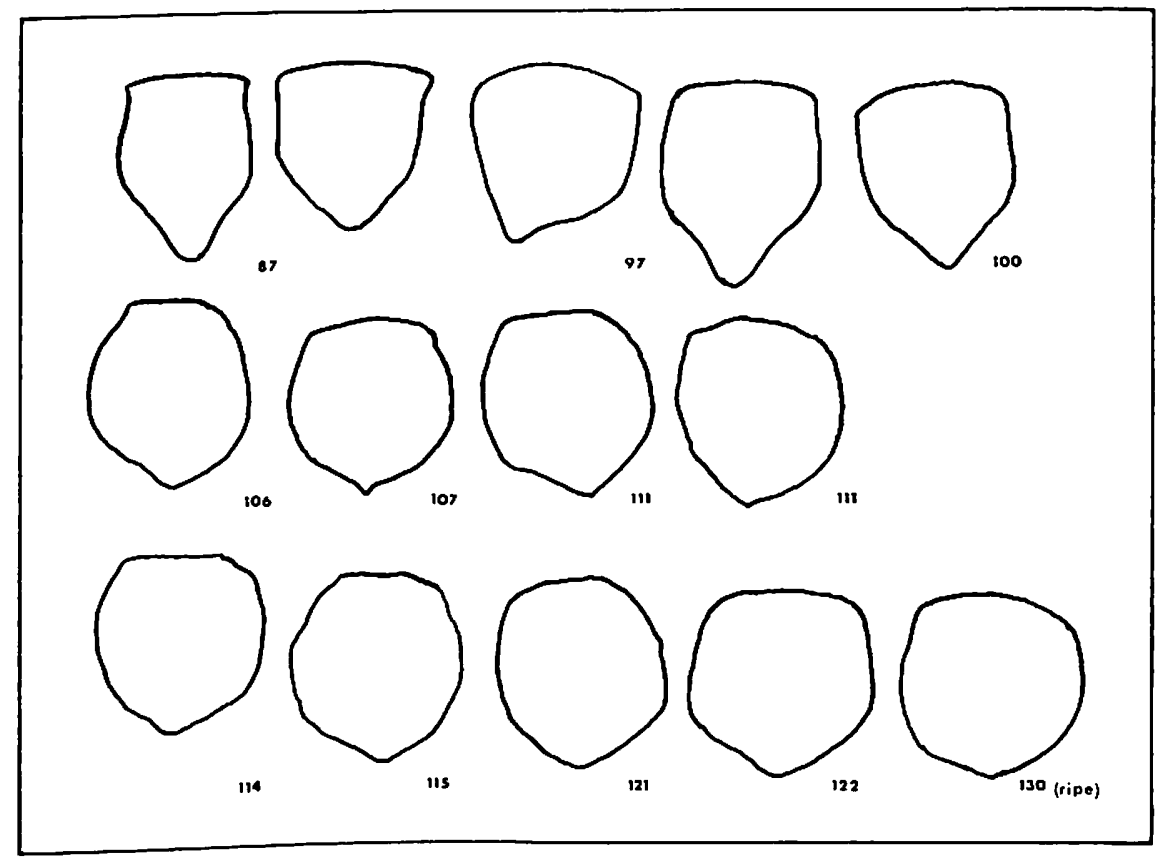

FIc. 2.--Changes in the cross-section of the plantain fruit with age.

significant at the 5-percent level and at the 1-percent level for the Maricongo. In figures 4 and 5 the values for the pulp: peel ratios for the different samples measured together with the regression equations have been plotted against. the age. The variation in pulp:peel ratios is linear and, if the regression 

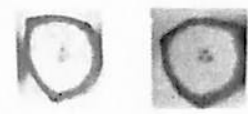

81

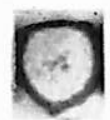

90

96
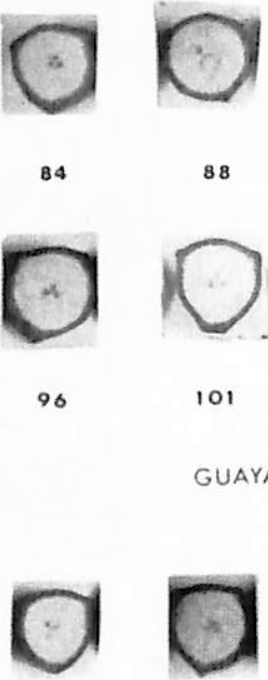

75

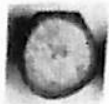

90

90

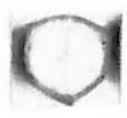

105

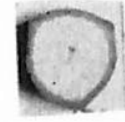

108

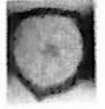

75

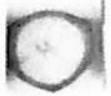

95

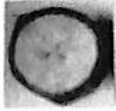

109
88

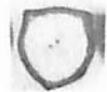

88

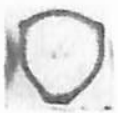

101

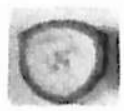

101

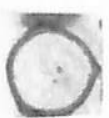

9

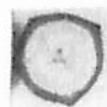

95

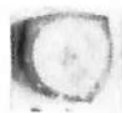

105

108

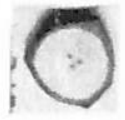

95
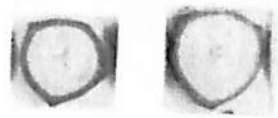

108

\section{GUAYAMERO SELECTION}

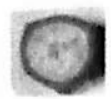

82

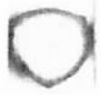

95

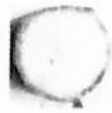

115

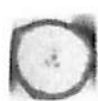

82

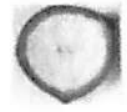

98

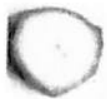

98
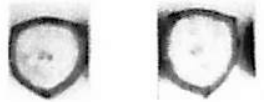

87

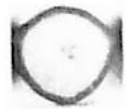

105

Fici. 3.-Photographs of the cross-section of plantains harvested at different ages. Numbers below each figure indicate the age at harvesting measured from inflorescence.

equations for both cultivars were plotted on the same graph, the curves could be superimposed.

A highly significant correlation was also found between age and shearpress values, as shown by the data in table 4 .

Analysis of the data also showed significant correlation at the 5-percent 
level between the average weight of the fruit and age in the Maricongo cultivar, but no similar correlation was found in plantains of the Guayamero cultivar.

Variations in the weight of the bunches with the age at harvesting for both cultivars are shown in table 5 . Because the weight of the bunches

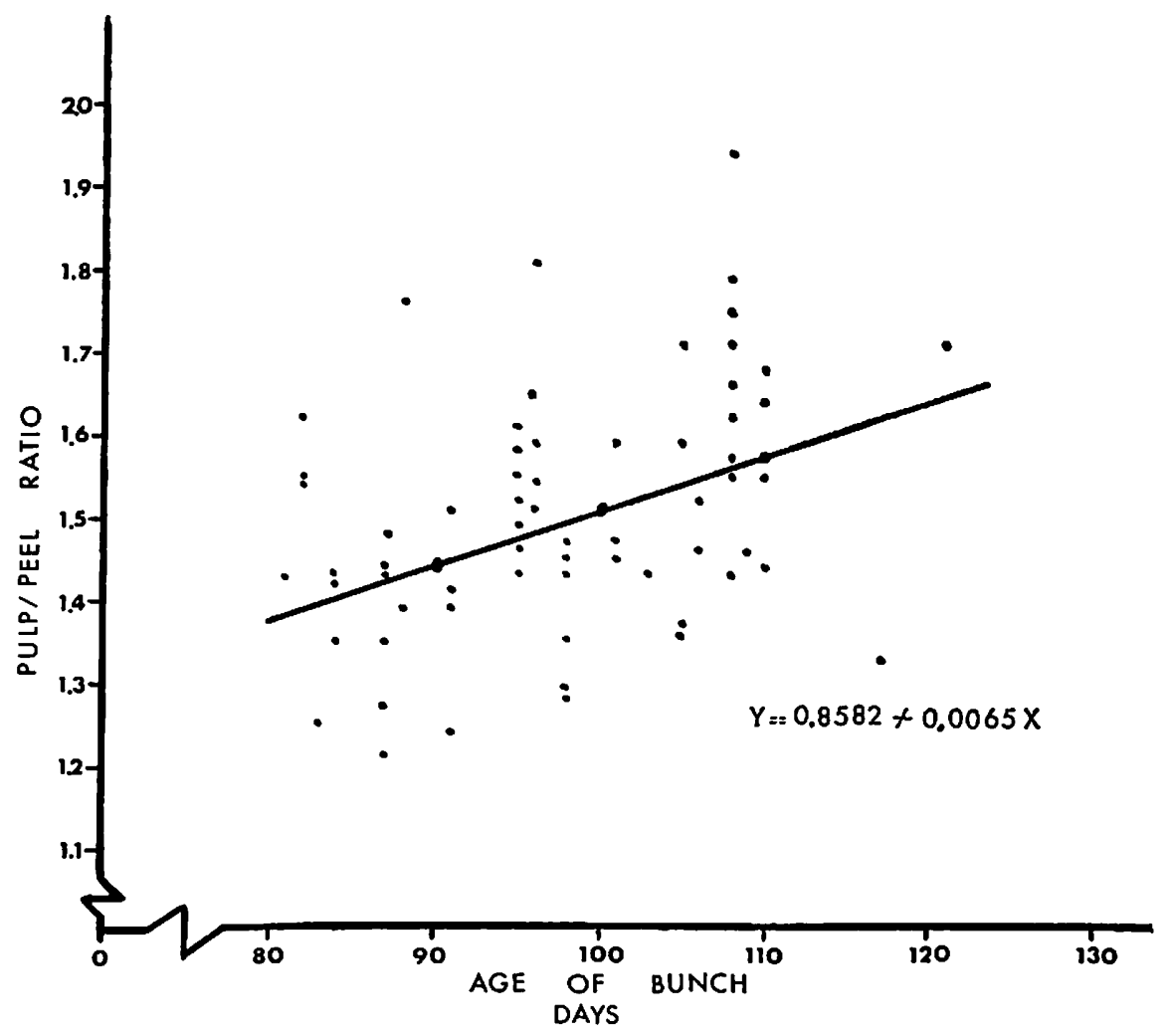

Frg. 4-Variations of pulp: peel ratios of plantains with age, Maricongo cultivar.

harvested at any age varies within wide limits, the increase in the weight of the bunches with age does not follow any definite pattern.

Throughout these studies, the age of plantains at harvesting was measured from the time the inflorescence was visible. Other alternatives are possible: Measuring the age from shooting or from the date the bunch finally shoots. These three stages are shown in figure 6 . From our experience it seems preferable to measure the age from the time the inflorescence becomes visible, or when the bunch shoots. Correlation analysis of the ratio of pulp:peel and shear-press values with age as measured from these two 


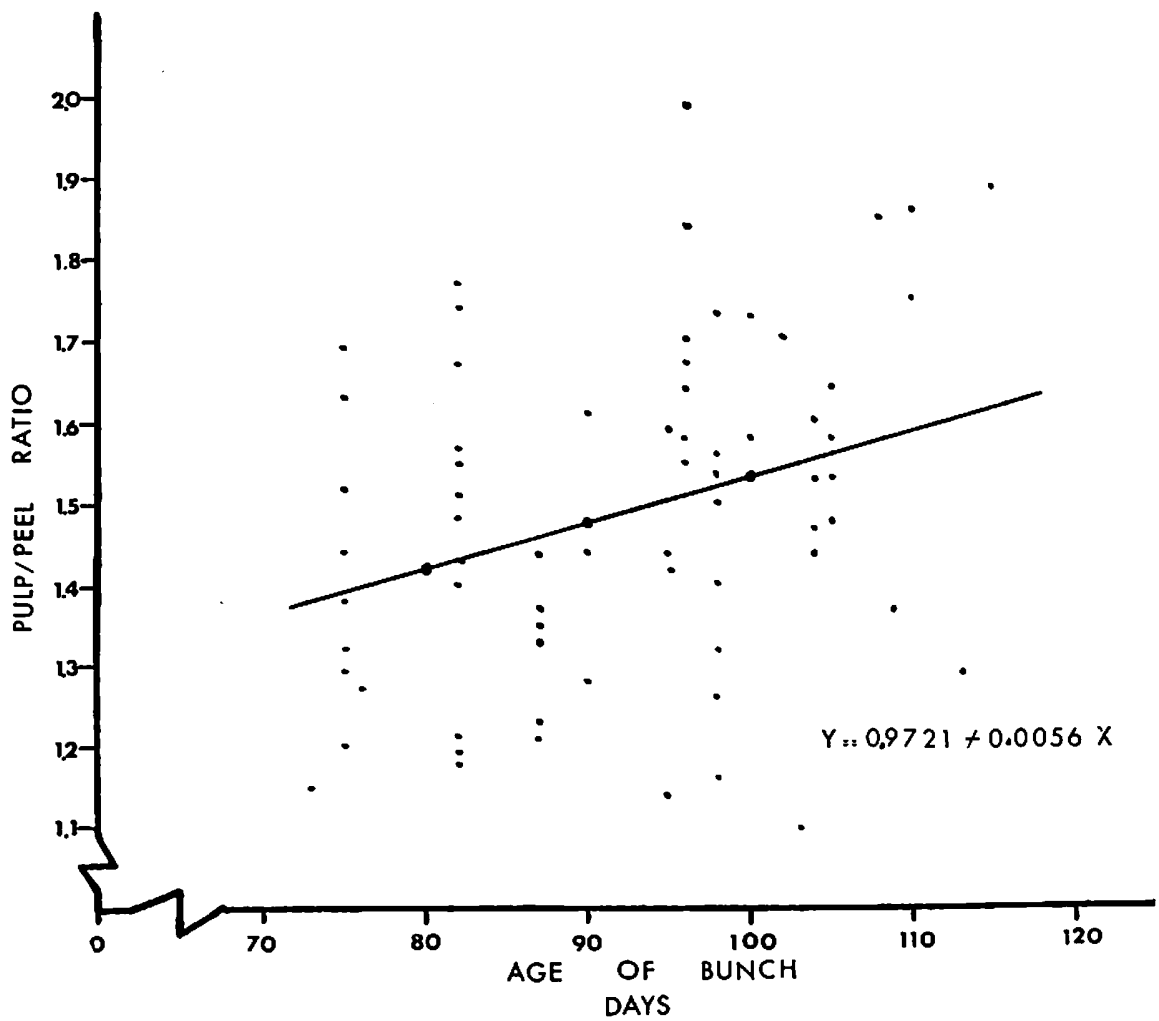

FIG. 5.-Variations of pulp: peel ratios of plantains with age, Guayamero cultivar.

TABLE 5.-Variation in the weight of plantain bunches of the Maricongo and Gnayamero cullivars harvested at the ages indicated

\begin{tabular}{c|c|c|c|c}
\hline & \multicolumn{4}{|c}{ Weight of bunch in pounds } \\
\cline { 2 - 5 } $\begin{array}{c}\text { Age in days } \\
\text { from visible } \\
\text { inflorescence }\end{array}$ & \multicolumn{3}{|c|}{ Range } & \multicolumn{2}{c}{ Mean } \\
\cline { 2 - 5 } & Maricongo & Guayamero & Maricongo & Guayamero \\
\hline $70-75$ & - & $9.5-18.0$ & - & 14.6 \\
$96-80$ & - & - & - & - \\
$81-85$ & $8.5-26.5$ & $8.0-22.0$ & 17.9 & 15.0 \\
$86-90$ & $12.8-24.0$ & $10.5-29.3$ & 18.9 & 17.7 \\
$91-95$ & $13.5-31.0$ & $9.0-24.0$ & 19.6 & 16.8 \\
$96-100$ & $12.5-25.0$ & $11.0-31.0$ & 19.2 & 19.1 \\
$101-105$ & $16.0-28.0$ & $13.5-29.5$ & 20.6 & 22.5 \\
$105-110$ & $19.0-27.5$ & $12.5-31.5$ & 22.0 & 21.8 \\
\hline
\end{tabular}


points show that both methods are equally reliable. Table 6 shows the correlation coefficients that were obtained from the analysis of the data, which were found to be significant to the 1-percent probability level.

The numerical values for the age measured from the time that the inflorescence is visible varies from that measured at the time the bunch shot by the interval in days between each event. For both cultivars the mean

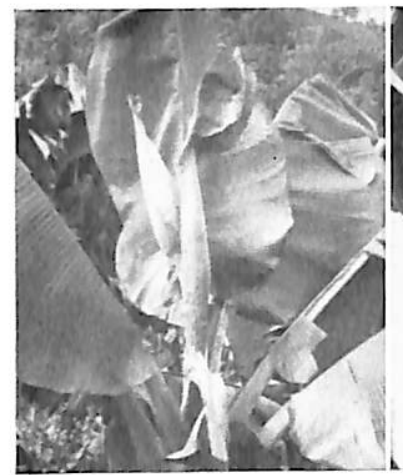

Inflorescence Visible

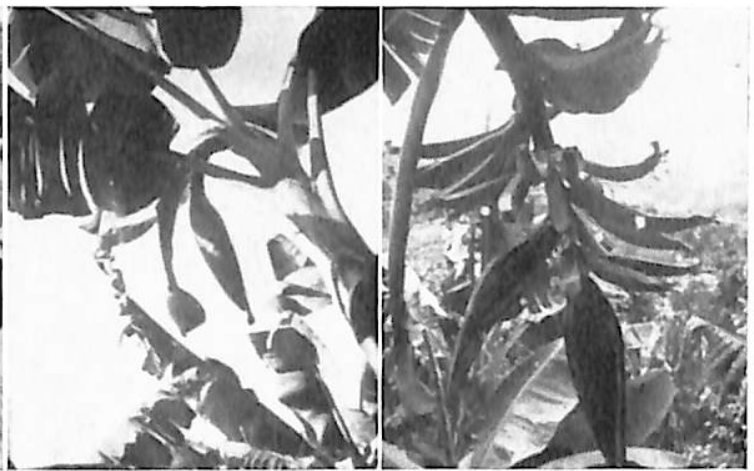

Bunch Shot

FIG. 6.-Stage of inflorescence, bunch shooting and at which the bunch shot.

TAвLE 6-Effect of measuring the age of plantain bunches from the time the bunch shot, or the inflorescence was visible, on the correlation of age with the ratio of pulp:peel weights and shear-press values

\begin{tabular}{l|c|c|c}
\hline \multicolumn{1}{c|}{ Age measured when- } & Correlation tested & $\begin{array}{c}\text { Correlation coefficient } \\
\text { calculated }\end{array}$ & $\begin{array}{c}\text { Level of } \\
\text { significance (percent) }\end{array}$ \\
\cline { 2 - 3 } Bunch shot & $\begin{array}{c}\text { Age } v s . \text { ratio of pulp } \\
\text { to peel }\end{array}$ & 0.358 & 1 \\
Inflorescence visible & $\begin{array}{c}\text { do. } \\
\text { Bunch shot }\end{array}$ & .376 & 1 \\
Inflorescence visible & $\begin{array}{c}\text { Shear-press values } \\
\text { do. }\end{array}$ & .836 & 1 \\
& & .803 & 1 \\
\hline
\end{tabular}

value for the interval from inflorescence to shooting was found to be 8.3 days and from inflorescence to the time the bunch shot, 19.6 days. Thus a bunch harvested 100 days after the inflorescence is visible would have an age of 92 days after shooting and 72 days from the time the bunch shot.

In conducting these studies, the authors were mainly concerned with the measurement of characteristics which could be used to harvest plantains at an optimum stage of development for processing. The results of this work show that only texture measurements with the shear press and pulp:peel ratios show high correlation with age. 
Table 7 shows how the quality and appearance rating of fried plantain slices prepared from frozen green plantains were affected by the age at which the fruit was harvested. The slices receiving the higher rating were those prepared from plantains harvested when older. Shear-press measurements indicate that plantains become softer as they mature, which suggests that the change in texture taking place during the maturation process is an important quality-determining factor.

The increase in pulp: peel ratios with maturity is also important to the processor, since as the pulp:peel ratio increases in value, yields of pulp and therefore, of processed products, are higher. A change in the pulp:peel ratio from a value of 1.38 to 1.50 results in an increase of 2 percent in the pulp available for processing.

TABLE 7.-Effect of age on the quality of frozen green plantain slices

\begin{tabular}{c|c|c}
\hline \multirow{2}{*}{$\begin{array}{c}\text { Age at harvesting } \\
\text { (days) }\end{array}$} & \multicolumn{2}{|c}{ Rating in a 5-point scale } \\
\cline { 2 - 3 } & Overall quality & Appearance \\
\hline 70 & 2.7 & 2.4 \\
79 & 2.7 & 2.9 \\
86 & 2.7 & 3.0 \\
100 & 3.8 & 3.9 \\
104 & 3.0 & 3.4 \\
105 & 3.8 & 3.7 \\
106 & 4.3 & 4.1 \\
\hline
\end{tabular}

From the standpoint of product quality, and to obtain maximum yields of processed products, the plantains should be harvested when as mature as possible, but still in the green stage. Although it has been shown that both the shear-press values and the pulp:peel ratios indicate the stage of maturity, these measurements do not lend themselves well to use as maturity indices, since both are destructive and difficult to use for field measurements. These indices, however, are of great value in harvesting and processing studies and can be used to correlate maturity with processing characteristics and product quality. In the conditions under which plantains are produced in Puerto Rico, where small farmers produce a high percentage of the crop in rugged terrain, measuring the age to determine harvesting time will be of little practical value. Besides, the data being collected from other experiments now in progress suggest that the time required for the plantains to develop to the proper stage for processing depends on the following factors: Time of the year at which flowering and fruit-set occur, prevailing weather conditions, geographical zone, vigor of plants, diseases, and clonal characteristics. With information now available from one sector 
of the Island and from three experimental plots which produced fruit at a certain time of the year only, no generalities can be made on the proper age for harvesting. When commercial plantations are established to provide plantains to the processing industry, data on the age at which plantains should be harvested must be taken at different times of the year, and for different geographical zones for planning harvesting schedules.

The data from these studies suggest that plantains should be harvested for processing when the pulp content is over 60 percent, which corresponds to a pulp:peel ratio over 1.5. At this stage the fruit is plump with the edges slightly pronounced. Until additional data are available to make possible the establishment of more accurate methods for judging maturity for harvesting, fruit of adequate quality for processing can be harvested by judging the stage of maturity from the angularity, and the general appearance of the fruit.

\section{SUMMARY}

A study was conducted to determine the preharvest changes in the physical and chemical characteristics of plantains of the Guayamero and Maricongo cultivars. The average weight of the fruit, the length of the fruit, the cross-sectional dimensions, pulp texture, and pulp:peel ratios were determined for each hand of the bunch at several time intervals after flowering. Starch, total and reducing-sugar content, total acidity, and $\mathrm{pH}$ were also measured in fruit from the third hand.

Statistical analysis of the data on the measurements taken from fruit from the third hand shows significant correlations between age and pulp: peel ratios. A highly significant correlation was also found between age and texture, the fruit becoming softer as it matured. A significant correlation at the 5-percent level was found bctween age and average fruit-weight in the Maricongo cultivar, but no similar correlation was found in plantains of the Guayamero cultivar.

The fruit becomes more plump and round with age, but wide variations in the cross-sectional area in fruit harvested at any age made it impossible to correlate cross-sectional dimensions with age.

Analysis indicated that no changes in the chemical composition of the fruit took place.

The quality and appearance ratings of fried-plantain slices prepared from frozen green plantains were affected by the age at which the fruit was harvested. Higher quality products were prepared from the more mature fruit. Since not only the quality of processed products, but also the yields are affected by the stage of maturity at which the fruit is harvested, fruit for processing should be harvested when as mature as possible, but still in the green stage. 


\section{RESUMEN}

Se llevó a cabo un estudio con las selecciones de plátanos Guayamero y Maricongo para determinar los cambios físicos y químicos que tienen lugar en la fruta mientras se desarrolla en la mata.

Se determinó el peso promedio de la fruta, el largo, el tamaño de la sección transversal, la textura de la pulpa y la razón entre el peso de la pulpa y el de la cáscara, en las frutas de cada mano de los racimos que se cosecharon a distintos intervalos de tiempo, después de la florecida. También se determinó el contenido de almidón y azúcares totales y reductoras, la acidez total, y el pH en las frutas de la tercera mano.

El análisis estadístico de los datos que se obtuvieron al medir las frutas de la tercera mano del racimo, revelan que existe una correlación significativa entre la edad de la fruta y la textura, así como entre la edad y la razón de pulpa a cáscara. En los plátanos Maricongo se observó una correlación significativa a un nivel de probabilidad del 5 por ciento, entre el peso promedio de la fruta y la edad, pero esta misma relación no pudo establecerse con los plátanos Guayameros.

Según madura la fruta, va adquiriendo una forma más redonda y los filos son menos pronunciados. Sin embargo, debido a que la apariencia de la sección transversal de la fruta no es uniforme, aun en las frutas cosechadas a una misma edad, no fue posible correlacionar las medidas de los diámetros de la sección transversal con la edad.

No se observaron cambios de importancia en la composición química de la fruta al analizarse.

La calidad y la apariencia de los tostones que se prepararon de la fruta cosechada a distintas edades y congelada, varió según la edad. El producto de mejor calidad fue el que se preparó de la fruta que permaneció más en la mata.

Tambièn se observó que el rendimiento de productos elaborados es mayor cuando la fruta se cosecha después de alcanzar un desarrollo avanzado. Esto se debe a que a medida que la fruta se desarrolla, aumenta el porcentaje de pulpa mientras disminuye el de cáscara. Toda vez que tanto la calidad como el rendimiento de los productos que se elaboran del plátano dependen del estado de desarrollo de la fruta al cosecharse, la fruta que se destina a la elaboración debe cosecharse todavía verde, pero bien desarrollada.

\section{LITERATURE CITED}

1. López Irizarry, R., Harina de Plátano, El Crisol 1 (6): 3-10, 1947.

2. Rahman, Abdul R., Economical method for the production of flour from green plantains, J. Agr. Univ. P.R. 47 (1): 1-10 1963.

3. Facts and Figures on Puerto Rico's Agriculture, Commonwealth of Puerto Rico, USDA, Office of Agr. Statist., p. 19, 1965. 
4. Cancel, L. E., González, M. A., and Sánchez Nieva, F., Elaboración del Platanutre, Agr. Expt. Sta. Univ. de P.R., Food Tech. Lab., Misc. Pub. 6, pp. 18, 1962.

5. Sánchez Nieva, F., and Hernández, I., Preparación y Conservación por Congelación de Plátanos Máduros en Almíbar, Agr. Expt. Sta. Univ. de P.R., Food Tech. Lab., Misc. Pub. 7, 1967.

6. Carter, G. H., Neubert, A. M., Rapid determination of starch in apples, $J$. Agr. Food Chem. 2 (21): 1070-72, 1954.

7. Moyer, J. C., Holgate, K. C., Determination of alcohol-insoluble solids and sugar contents of vegetables, Anal. Chem. 20 (5): 472-4, 1948.

8. Methods of Analysis of the Association of Official Agricultural Chemists, 9th ed., Washington, D.C., p. 272, 1960.

9. Simmouds, N. W., Bananas, Longman, Green \& Co. Ltd., London, England, 1965.

10. Banana Ripening Manual, Fruit Dispatch Co., New York, N.Y., pp. 4, 1956. 